\title{
USULAN PERBAIKAN KUALITAS LAYANAN MASKAPAI PENERBANGAN X MENGGUNAKAN INTEGRASI QFD DAN MODEL KANO
}

\author{
DEDE JATMIKA PRAWIRA, MUHAMMAD IQBAL, DAN AMELIA KURNIAWATI \\ Program Studi Teknik Industri, Fakultas Rekayasa Industri, Institut Teknologi Telkom, Bandung \\ Laman: d_for_devilholic@yahoo.com
}

\begin{abstract}
ABSTRAK
Maskapai X mengalami isu peningkatan kualitas terkait dengan komplain yang ditujukan pada layanannya. Komplain mengalami peningkatan pada masa liburan dan hari raya terutama pada bulan Januari, Agustus, September, dan Oktober. Perbaikan diperlukan untuk menghasilkan layanan yang lebih baik. Layanan yang baik adalah salah satu aspek penting bagi kepuasan pelanggan. Kepuasan pelanggan dari maskapai penerbangan X diukur berdasarkan beberapa atribut. Atribut kualitas layanan juga dikelompokkan ke dalam kategori must be, one-dimensional, attractive, indifferent, questionable, dan reverse. Program peningkatan kualitas dirancang menggunakan metode Quality Function Deployment (QFD) dan model Kano. Hasil penelitian menunjukkan bahwa kepuasan pelanggan pada seluruh atribut belum dapat terpenuhi. Atribut penting yang teridentifikasi berdasarkan pengukuran kepuasan dan kategori Kano adalah ketepatan waktu keberangkatan sesuai jadwal (kategori one-dimensional), fasilitas hiburan di pesawat yang menarik (kategori attractive), fasilitas bagasi yang efisien (kategori one-dimensional), makanan di pesawat enak dan berkualitas baik (kategori one-dimensional), dan staf terampil dalam melayani pelanggan (kategori one-dimensional). Rekomendasi penelitian ini adalah pengecekan rutin untuk mencegah keterlambatan, pemberian kompensasi pada saat terjadi keterlambatan, penerapan program airlines staff service excellence, penerapan program cooking class, dan pemberian fasilitas hiburan yang berteknologi dan up to date pada pesawat.
\end{abstract}

Kata kunci: kano, kualitas layanan, layanan penerbangan, QFD

\begin{abstract}
$X$ Airlines is experiencing quality improvement issue related to complaints addressed to their service. Complaints are increasing in holiday and feast day, especially on January, August, September, and October. Improvement is needed to produce better service and better sevice is one of the key aspect of customer satisfaction. Customer satisfaction of X Airlines was measured based on several attributes. The service quality attributes were also grouped into must be, one dimensional, attractive, indifferent, questionable, and reverse category. The quality improvement was designed by using Quality Function Deployment (QFD) method and Kano Model. The result showed that customer's satisfaction in all service quality attributes were still not being met the requrement. The key attribute indentified on satisfaction measurement and the Kano Category were the on time of departure corresponding to the schedule (one dimensional category), the efficient language storage facilities (one dimensional category), the tasty and good quality of the food (one dimensional category), and skilled staffs in serving the customer avoid tardiness, giving compensation when tardiness happened, conducting airlines staff service excellence program, conducting cooking class program, and providing high technology and up to date entertainment facilities on the plane.
\end{abstract}

Key words: kano, service quality, airline service, $Q F D$

\section{PENDAHULUAN}

Maskapai Penerbangan X yang merupakan perusahaan yang bergerak dalam bidang jasa penerbangan, berusaha memberikan kualitas layanan yang terbaik bagi konsumen yang menggunakan jasanya. Dari Gambar 1 dapat disimpulkan bahwa masih banyak pelanggan yang kurang puas dengan pelayanan maskapai penerbangan $\mathrm{X}$ terutama pada bulan Januari, Agustus, September dan Oktober. Pada bulan-bulan tersebut tingkat komplain pelanggan meningkat karena adanya hari raya dan hari liburan, tidak sedikit pelanggan yang kurang puas dengan layanan Maskapai Penerbangan X baik itu tentang delay pesawat, bagasi rusak, uncomfortable landing, dan lain-lain yang mengakibatkan image maskapai penerbangan X di mata pelanggan menurun. Adanya 
komplain dari pelanggan menunjukkan bahwa Maskapai Penerbangan X harus memperbaiki kinerja layanannya.

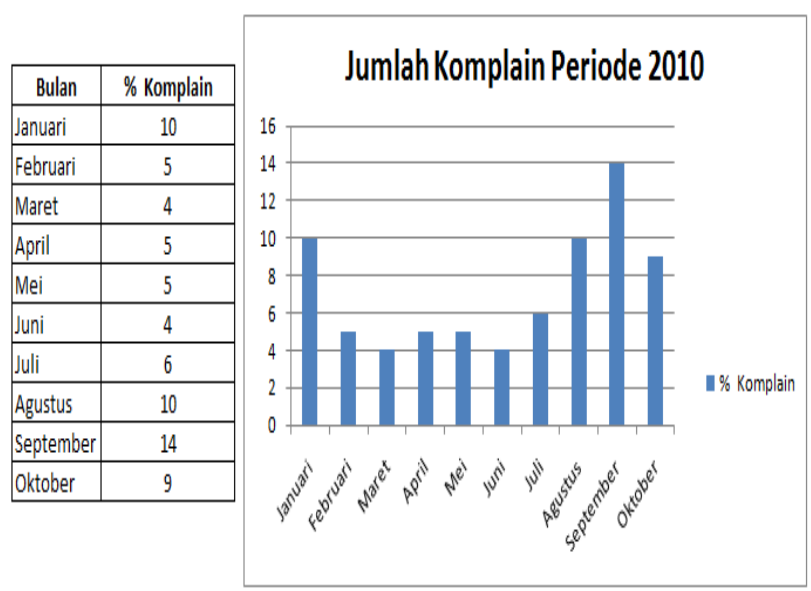

Gambar 1. Jumlah Komplain Pelanggan terhadap Maskapai Penerbangan X

Dengan pertimbangan di atas, maka Maskapai Penerbangan X perlu melakukan suatu riset atau penelitian untuk mengetahui harapan konsumen terhadap kualitas jasa dan sejauh mana kualitas layanan Maskapai Penerbangan X menurut konsumennya. Dengan menerapkan metode Quality Function Deployment (QFD) dan Model Kano, maka Maskapai Penerbangan X dapat melakukan suatu peningkatan kualitas layanan yang disesuaikan dengan kebutuhan dan keinginan konsumen. Politis (2005) menyatakan QFD telah diketahui mampu membantu berbagai organisasi untuk dapat menghasilkan perbaikan kinerja dengan menerjemahkan kebutuhan pelanggan ke produk atau layanan yang baik.

Penelitian ini bertujuan untuk merumuskan rekomendasi perbaikan kualitas untuk Maskapai Penerbangan X. Pada penelitian ini akan diidentifikasi atribut kebutuhan pelanggan serta tingkat kepentingan dan kepuasan atribut tersebut. Selanjutnya akan diidentifikasi karakteristik teknis yang relevan dengan atribut kebutuhan. Karakteristik teknis yang sudah diprioritaskan akan menjadi pedoman untuk rekomendasi perbaikan. Dengan demikian sumber daya yang dimiliki Maskapai Penerbangan X dapat dialokasikan secara optimal untuk mewujudkan kepuasan konsumen secara maksimal.

\section{METODE}

Atribut kebutuhan merupakan segala hal yang dianggap oleh konsumen penting dan dibutuhkan dalam sebuah produk atau jasa. Atribut kebutuhan dapat diperoleh melalui wawancara baik secara langsung maupun tidak langsung dengan konsumen. Konsumen yang dimaksud adalah orang-orang yang telah menggunakan jasa penerbangan $\mathrm{X}$ lebih dari satu kali. Data ini digunakan sebagai acuan dalam menentukan ekspektasi dan persepsi pelanggan terhadap layanan penerbangan yang dirasakan pelanggan saat ini. Tingkat ekspektasi merupakan nilai yang diharapkan oleh konsumen dalam sebuah produk atau jasa dan tingkat persepsi adalah nilai yang dirasakan oleh konsumen terhadap suatu produk atau jasa (Parasuraman dkk., 1996).

Perbandingan antara nilai harapan dan persepsi ini akan menentukan nilai gap (kesenjangan) dari kualitas layanan yang diberikan oleh Maskapai Penerbangan X. Dari nilai servqual ini akan diperoleh atribut-atribut penting yang dijadikan sebagai Voice of Customer. Voice of Customer (VOC) merupakan seluruh atribut yang yang akan digunakan dalam perancangan HOQ. Ulrich dan Epingger (2008) menyebutkan bahwa House of Quality (HOQ) adalah sebuah teknik grafis yang digunakan dalam Quality Function Deployment (QFD). Cohen dan Joseph (2009) menjelaskan bahwa dalam memenuhi VOC maka yang dapat dilakukan perusahaan adalah menentukan suatu ukuran yang digunakan dalam mencari solusi atas kebutuhan-kebutuhan yang diinginkan pelanggan, hal ini sering disebut dengan nama karakteristik teknis.

Model kano merupakan tools yang digunakan dalam mengkategorikan atribut kebutuhan pelanggan dalam kriteria yang telah ditetapkan dalam model kano tersebut. Kemudian dari data yang diperoleh tersebut dilakukan juga perhitungan terhadap bobot dari setiap kategori kano, kemudian disusun menjadi pertanyaan-pertanyaan dalam bentuk kuesioner yang merupakan gabungan dari kuesioner servqual dan kuesioner model kano. Seluruh data akan diproses ke dalam program peningkatan kualitas layanan seperti apa yang sesuai dengan kebutuhan dan keinginan konsumen dengan menggunakan metode Quality Function Deployment. Berdasarkan framework dari integrasi kano's model dan servqual ke dalam QFD maka didapatkan struktur dari HOQ yang dapat dilihat pada Gambar 2. Hasil dari perancangan tersebut akan menjadi program peningkatan kualitas layanan maskapai penerbangan X.

\section{HASIL DAN PEMBAHASAN}

\section{Atribut Kebutuhan Layanan}

Berdasarkan identifikasi voice of customer, terdapat 30 atribut kebutuhan layanan maskapai penerbangan berdasarkan dimensi servqual, yaitu tangible, reliability, assurance, responsiveness dan 


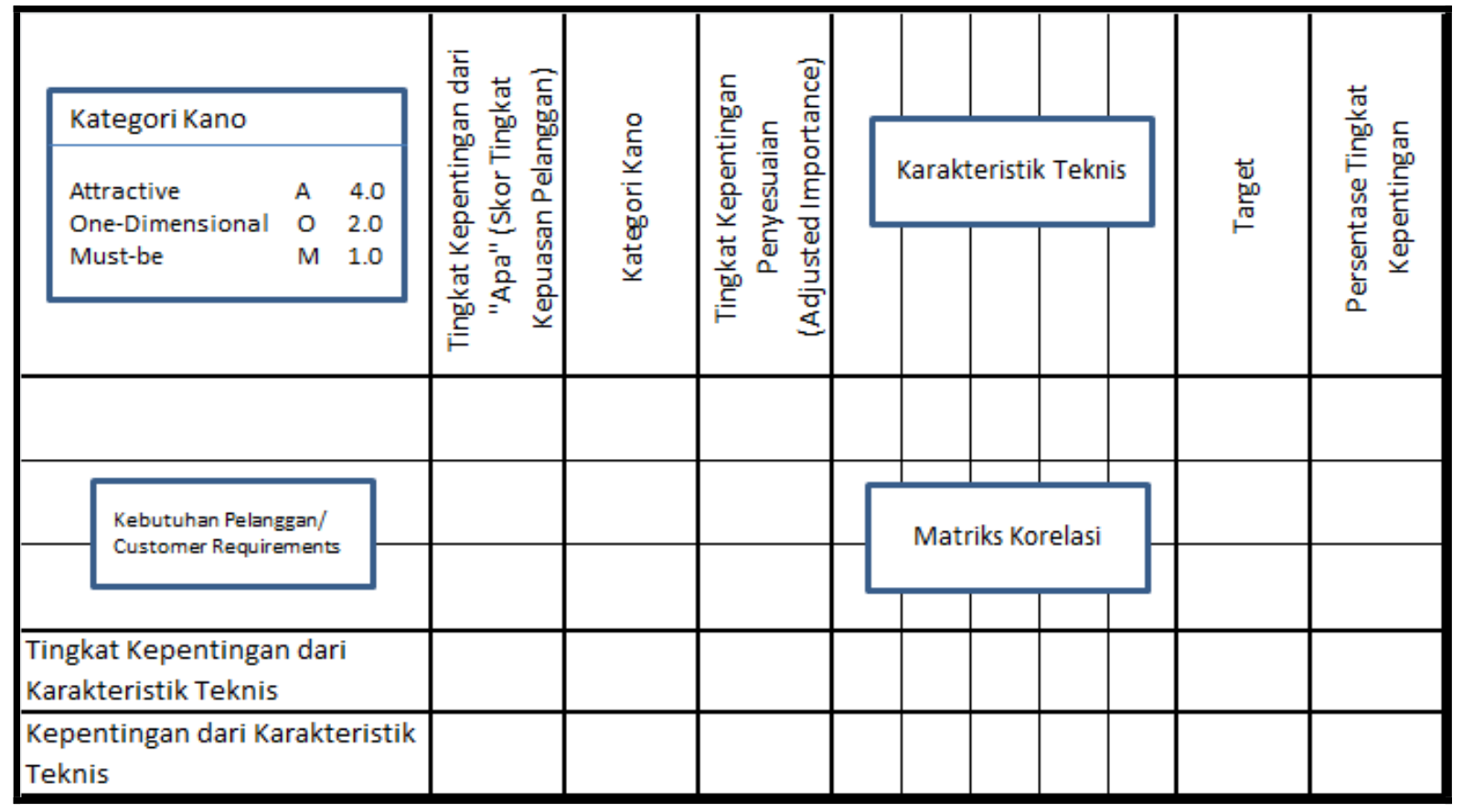

Sumber: Tan dan Pawitra (2001)

Gambar 2. Struktur House of Quality dengan Pendekatan Terintegrasi

Tabel 1. Tingkat Kepuasan Pelanggan

\begin{tabular}{|c|c|c|c|}
\hline Atribut Kebutuhan & Expected & Perceived & Satisfaction \\
\hline Ruangan counter tiket yang rapi & 4.2909 & 3.4091 & -0.8818 \\
\hline Staf maskapai penerbangan berbicara sopan dalam melayani konsumen & 4.5864 & 4.0182 & -0.5682 \\
\hline Staf dapat memberikan pelayanan administrasi secara cepat kepada konsumen & 4.3045 & 3.3182 & -0.9864 \\
\hline Staf maskapai penerbangan menyambut dengan ramah pada konsumen & 4.3591 & 3.4727 & -0.8864 \\
\hline Fasilitas ruang duduk yang luas dan nyaman & 4.0364 & 3.6273 & -0.4091 \\
\hline Fasilitas berbelanja yang lengkap di pesawat & 4.4227 & 3.5864 & -0.8364 \\
\hline Fasilitas hiburan di pesawat yang menarik & 4.4000 & 3.3000 & -1.1000 \\
\hline Ketepatan waktu keberangkatan sesuai dengan jadwal yang telah ditetapkan & 4.6682 & 2.4909 & -2.1773 \\
\hline Fasilitas koran/majalah di pesawat yang lengkap & 4.4636 & 3.2955 & -1.1682 \\
\hline Fasilitas kabin pesawat yang luas & 4.5318 & 3.8409 & -0.6909 \\
\hline Suhu ruangan pesawat yang sejuk dan nyaman & 4.6636 & 3.7045 & -0.9591 \\
\hline Kebersihan kabin dan tempat duduk & 4.5000 & 3.3545 & -1.1455 \\
\hline Penampilan staf yang rapi dan menarik & 4.1318 & 3.5591 & -0.5727 \\
\hline Makanan dan minuman di pesawat yang lengkap & 4.2591 & 3.6409 & -0.6182 \\
\hline Kecukupan jumlah staf maskapai penerbangan yang ada & 4.2409 & 3.5500 & -0.6909 \\
\hline Staf dapat bersikap professional terhadap konsumen & 4.4227 & 3.4955 & -0.9273 \\
\hline Staf tanggap terhadap permintaan konsumen & 4.4773 & 3.3409 & -1.1364 \\
\hline Pelayanan pesanan makanan dan minuman yang cepat & 4.5136 & 3.2909 & -1.2227 \\
\hline Makanan di pesawat yang enak (kualitas makanan) & 4.5864 & 2.9091 & -1.6773 \\
\hline Keamanan dan keutuhan bagasi yang terjamin & 4.4227 & 3.7364 & -0.6864 \\
\hline Kemudahan dalam pembayaran tiket (kartu kredit) & 4.3773 & 3.8227 & -0.5545 \\
\hline Minuman di pesawat yang enak (kualitas minuman) & 4.4182 & 3.7500 & -0.6682 \\
\hline Adanya transportasi atau gateway ke pesawat & 4.3455 & 3.5273 & -0.8182 \\
\hline Fasilitas penyimpanan bagasi yang efisien & 4.5136 & 2.8091 & -1.7045 \\
\hline Kebersihan lavatory & 4.5091 & 3.4682 & -1.0409 \\
\hline Fasilitas safety di pesawat yang terjamin mutunya & 4.6727 & 3.5409 & -1.1318 \\
\hline Staf bersikap komunikatif terhadap konsumen & 4.3545 & 3.2591 & -1.0955 \\
\hline Staf mampu memahami dan peduli terhadap kebutuhan konsumen & 4.1727 & 2.9227 & -1.2500 \\
\hline Staf dapat menyampaikan informasi dengan jelas dan akurat & 4.2682 & 3.0045 & -1.2636 \\
\hline Staf terampil dalam melayani konsumen & 4.3773 & 3.3773 & -1.0000 \\
\hline
\end{tabular}


empathy. Identifikasi voice of customer ini dilakukan dengan cara wawancara terhadap 30 orang pengguna layanan maskapai penerbangan X. Voice of Customer merupakan representasi dari keinginan pelanggan terkait layanan yang diberikan oleh maskapai penerbangan X. Atribut-atribut kebutuhan layanan untuk maskapai penerbangan X ditampilkan pada Tabel 1.

\section{Tingkat Kepuasan Pelanggan}

Identifikasi tingkat kepuasan pelanggan dilakukan berdasarkan hasil kuesioner yang diisi oleh sejumlah 220 orang responden pengguna layanan maskapai penerbangan $\mathrm{X}$. Indikator yang digunakan untuk mengukur tingkat kepuasan pelanggan adalah atribut-atribut kebutuhan layanan yang telah diidentifikasi sebelumnya. Tingkat kepuasan (customer satisfaction) dihitung berdasarkan selisih antara tingkat harapan (expected service) dan tingkat kenyataan (perceived service).

Berdasarkan hasil perhitungan, terlihat bahwa nilai kepuasan pelanggan untuk seluruh atribut kebutuhan adalah negatif. Hal ini menunjukkan bahwa secara umum, pelanggan belum merasa puas terhadap layanan yang diberikan oleh maskapai penerbangan X. Nilai kepuasan pelanggan untuk setiap atribut kebutuhan dapat dilihat pada Tabel 1. Terdapat empat belas atribut yang memiliki tingkat kepuasan lebih kecil sama dengan -1 (diberi warna abu-abu).

\section{Model Kano}

Kuesioner Kano disebarkan kepada 220 orang pelanggan yang juga mengisi kuesioner kepuasan pelanggan. Hasil kuesioner Kano yang berupa respons pelanggan terhadap pernyataan fungsional dan disfungsional akan diklasifikasi menjadi kriteria-kriteria kano berdasarkan tabel evaluasi kano, seperti pada Tabel 2. Kemudian hasil pengklasifikasian tersebut akan ditabulasikan sehingga didapatkan hasil kriteria Kano untuk setiap customer requirement.

Tabel 2. Tabel Evaluasi Kano

\begin{tabular}{cccccc}
\hline \multirow{2}{*}{$\begin{array}{c}\text { Kebutuhan } \\
\text { Konsumen }\end{array}$} & \multicolumn{5}{c}{ Dysfunctional } \\
\cline { 2 - 6 } & $\mathbf{1}$ & $\mathbf{2}$ & $\mathbf{3}$ & $\mathbf{4}$ & $\mathbf{5}$ \\
\cline { 2 - 6 } Suka & Harap & Netral & Toleransi & Tidak Suka \\
\hline Functional 1. Suka & $\mathrm{Q}$ & $\mathrm{A}$ & $\mathrm{A}$ & $\mathrm{A}$ & $\mathrm{O}$ \\
2. Harap & $\mathrm{R}$ & $\mathrm{I}$ & $\mathrm{I}$ & $\mathrm{I}$ & $\mathrm{M}$ \\
3. Netral & $\mathrm{R}$ & $\mathrm{I}$ & $\mathrm{I}$ & $\mathrm{I}$ & $\mathrm{M}$ \\
4. Toleransi & $\mathrm{R}$ & $\mathrm{I}$ & $\mathrm{I}$ & $\mathrm{I}$ & $\mathrm{M}$ \\
5. Tidak Suka & $\mathrm{R}$ & $\mathrm{R}$ & $\mathrm{R}$ & $\mathrm{R}$ & $\mathrm{Q}$ \\
\hline
\end{tabular}

Sumber: Rao (1996)

$\mathrm{A}=$ Attractive $; \mathrm{M}=$ Must-be $; \mathrm{O}=$ One-dimensional $;$ $\mathrm{I}=$ Indifferent $; \mathrm{R}=$ Reverse $; \mathrm{Q}=$ Questionable
Tabel 3. Pengkategorian Atribut ke dalam Kategori Kano

\begin{tabular}{|c|c|c|}
\hline Atribut Kebutuhan & Grade Kano & Bobot \\
\hline Ruangan counter tiket yang rapi & $\mathrm{O}$ & 2 \\
\hline $\begin{array}{l}\text { Staf maskapai penerbangan berbicara } \\
\text { sopan dalam melayani konsumen }\end{array}$ & M & 1 \\
\hline $\begin{array}{l}\text { Staf dapat memberikan pelayanan } \\
\text { administrasi secara cepat kepada } \\
\text { konsumen }\end{array}$ & $\mathrm{O}$ & 2 \\
\hline $\begin{array}{l}\text { Staf maskapai penerbangan } \\
\text { menyambut dengan ramah pada } \\
\text { konsumen }\end{array}$ & M & 1 \\
\hline $\begin{array}{l}\text { Fasilitas ruang duduk yang luas dan } \\
\text { nyaman }\end{array}$ & $\mathrm{O}$ & 2 \\
\hline $\begin{array}{l}\text { Fasilitas berbelanja yang lengkap di } \\
\text { pesawat }\end{array}$ & I & 0 \\
\hline $\begin{array}{l}\text { Fasilitas hiburan di pesawat yang } \\
\text { menarik }\end{array}$ & A & 4 \\
\hline $\begin{array}{l}\text { Ketepatan waktu keberangkatan } \\
\text { sesuai dengan jadwal yang telah } \\
\text { ditetapkan }\end{array}$ & $\mathrm{O}$ & 2 \\
\hline $\begin{array}{l}\text { Fasilitas koran/majalah di pesawat } \\
\text { yang lengkap }\end{array}$ & $\mathrm{O}$ & 2 \\
\hline Fasilitas kabin pesawat yang luas & $\mathrm{O}$ & 2 \\
\hline $\begin{array}{l}\text { Suhu ruangan pesawat yang sejuk dan } \\
\text { nyaman }\end{array}$ & M & 1 \\
\hline Kebersihan kabin dan tempat duduk & $\mathrm{O}$ & 2 \\
\hline $\begin{array}{l}\text { Penampilan staf yang rapi dan } \\
\text { menarik }\end{array}$ & $\mathrm{O}$ & 2 \\
\hline $\begin{array}{l}\text { Makanan dan minuman di pesawat } \\
\text { yang lengkap }\end{array}$ & M & 1 \\
\hline $\begin{array}{l}\text { Kecukupan jumlah staf maskapai } \\
\text { penerbangan yang ada }\end{array}$ & M & 1 \\
\hline $\begin{array}{l}\text { Staf dapat bersikap professional } \\
\text { terhadap konsumen }\end{array}$ & $\mathrm{O}$ & 2 \\
\hline $\begin{array}{l}\text { Staf tanggap terhadap permintaan } \\
\text { konsumen }\end{array}$ & M & 1 \\
\hline $\begin{array}{l}\text { Pelayanan pesanan makanan dan } \\
\text { minuman yang cepat }\end{array}$ & $\mathrm{O}$ & 2 \\
\hline $\begin{array}{l}\text { Makanan di pesawat yang enak } \\
\text { (kualitas makanan) }\end{array}$ & $\mathrm{O}$ & 2 \\
\hline $\begin{array}{l}\text { Keamanan dan keutuhan bagasi yang } \\
\text { terjamin }\end{array}$ & $\mathrm{O}$ & 2 \\
\hline $\begin{array}{l}\text { Kemudahan dalam pembayaran tiket } \\
\text { (kartu kredit) }\end{array}$ & $\mathrm{O}$ & 2 \\
\hline $\begin{array}{l}\text { Minuman di pesawat yang enak } \\
\text { (kualitas minuman) }\end{array}$ & $\mathrm{O}$ & 2 \\
\hline $\begin{array}{l}\text { Adanya transportasi atau gateway ke } \\
\text { pesawat }\end{array}$ & $\mathrm{O}$ & 2 \\
\hline $\begin{array}{l}\text { Fasilitas penyimpanan bagasi yang } \\
\text { efisien }\end{array}$ & $\mathrm{O}$ & 2 \\
\hline Kebersihan lavatory & $\mathrm{O}$ & 2 \\
\hline $\begin{array}{l}\text { Fasilitas safety di pesawat yang } \\
\text { terjamin mutunya }\end{array}$ & M & 1 \\
\hline $\begin{array}{l}\text { Staf bersikap komunikatif terhadap } \\
\text { konsumen }\end{array}$ & I & 0 \\
\hline $\begin{array}{l}\text { Staf mampu memahami dan peduli } \\
\text { terhadap kebutuhan konsumen }\end{array}$ & $\mathrm{O}$ & 2 \\
\hline $\begin{array}{l}\text { Staf dapat menyampaikan informasi } \\
\text { dengan jelas dan akurat }\end{array}$ & $\mathrm{M}$ & 1 \\
\hline $\begin{array}{l}\text { Staf terampil dalam melayani } \\
\text { konsumen }\end{array}$ & $\mathrm{O}$ & 2 \\
\hline
\end{tabular}


Penentuan kategori Kano untuk tiap atribut dilakukan dengan menggunakan Blauth's formula seperti yang dipaparkan Tan dan Pawitra (2001), yaitu:

- Jika jumlah (one-dimensional + attractive + mustbe) $>$ jumlah (indifferent + reverse + questionable) maka grade diperoleh dari yang paling maksimum dari (one dimensional, attractive, must be)

- Jika jumlah (one-dimensional + attractive + must-be) $<$ jumlah (indifferent + reverse + questionable) maka grade diperoleh dari yang paling maksimum dari (indifferent, questionable, reverse)

Hasil dari tabulasi dan kategori yang ditentukan dari Blauth's formula dari masing-masing kriteria yang akan diusulkan perbaikannya dapat dilihat sebagai berikut. Hasil pengkategorian atribut ke dalam kategori Kano dapat dilihat pada Tabel 3. Atribut yang diberi warna abu-abu mengacu pada atribut yang nilai selisih antara tingkat harapan (expected service) dan tingkat kenyataan (perceived service) lebih kecil dari atau sama dengan -1 (seperti pada penjelasan Tabel 1). Hal ini menunjukkan atribut dengan nilai kepuasan yang terendah dibandingkan atribut yang lain. Nilai kano menunjukkan apakah atribut tersebut termasuk kategori attractive, mustbe, one-dimensional, atau indifferent dan nilai ini akan mempengaruhi adjusted importance seperti pada penjelasan berikutnya.

\section{Adjusted Importance}

Nilai adjusted importance merupakan nilai absolut atas perkalian masing-masing bobot kategori kano dengan nilai gap dan tingkat kepentingan.
Tabel 4. Adjusted Importance

\begin{tabular}{lc}
\hline \multicolumn{1}{c}{ Atribut Kebutuhan } & $\begin{array}{c}\text { Adjusted } \\
\text { Importance }\end{array}$ \\
\hline Fasilitas hiburan di pesawat yang menarik & 19.360 \\
Fasilitas koran/majalah di pesawat yang lengkap & 10.429 \\
Fasilitas penyimpanan bagasi yang efisien & 15.387 \\
Kebersihan kabin dan tempat duduk & 10.309 \\
Kebersihan lavatory & 9.387 \\
Ketepatan waktu keberangkatan sesuai dengan & 20.328 \\
$\quad$ jadwal yang telah ditetapkan & \\
Makanan di pesawat yang enak (kualitas & 15.385 \\
$\quad$ makanan) & 11.038 \\
Staf terampil dalam melayani konsumen & 5.088 \\
Staf tanggap terhadap permintaan konsumen & 8.755 \\
Pelayanan pesanan makanan dan minuman & \\
$\quad$ yang cepat & 5.289 \\
Fasilitas safety di pesawat yang terjamin & \\
$\quad$ mutunya & \\
Staf mampu memahami dan peduli terhadap & 10.432 \\
$\quad$ kebutuhan konsumen & \\
Staf dapat menyampaikan informasi dengan & 5.393 \\
$\quad$ jelas dan akurat & \\
\hline
\end{tabular}

Perhitungan ini dilakukan terhadap true customer needs. Tan dan Pawitra (2001) menjelaskan bahwa true customer needs diperoleh dengan mengeluarkan atribut yang memiliki grade kano indifference, yaitu atribut staf bersikap komunikatif terhadap konsumen pada Tabel 3. Hasil penghitungan adjusted importance dapat dilihat pada Tabel 4.

Nilai adjusted importance menggambarkan tingkat kepentingan dilihat dari tingkat harapan, rating Kano, dan gap (selisih) antara tingkat harapan dan tingkat kenyataan. Nilai yang besar menunjukkan kecenderungan atribut tersebut untuk diprioritaskan dikarenakan tingkat harapan terhadap

Tabel 5. Prioritas Perbaikan Customer Requirements

\begin{tabular}{|c|c|c|c|c|c|c|}
\hline $\begin{array}{c}\text { Kode } \\
\text { Atribut }\end{array}$ & Customer Requirement & Gap & Grade & $\begin{array}{c}\text { Adjusted } \\
\text { Importance }\end{array}$ & $\begin{array}{l}\% \text { Adjusted } \\
\text { Importance }\end{array}$ & $\operatorname{Rank}$ \\
\hline T3 & Fasilitas hiburan di pesawat yang menarik & -1.1000 & A & 19.360 & $13 \%$ & 2 \\
\hline T5 & Fasilitas koran/majalah di pesawat yang lengkap & -1.1682 & $\mathrm{O}$ & 10.429 & $7 \%$ & 7 \\
\hline $\mathrm{T} 7$ & Fasilitas penyimpanan bagasi yang efisien & -1.7045 & $\mathrm{O}$ & 15.387 & $10 \%$ & 3 \\
\hline $\mathrm{T} 10$ & Kebersihan kabin dan tempat duduk & -1.1455 & $\mathrm{O}$ & 10.309 & $7 \%$ & 8 \\
\hline $\mathrm{T} 11$ & Kebersihan lavatory & -1.0409 & $\mathrm{O}$ & 9.387 & $6 \%$ & 9 \\
\hline RE1 & $\begin{array}{l}\text { Ketepatan waktu keberangkatan sesuai dengan jadwal } \\
\text { yang telah ditetapkan }\end{array}$ & -2.1773 & $\mathrm{O}$ & 20.328 & $14 \%$ & 1 \\
\hline RE5 & Makanan di pesawat yang enak (kualitas makanan) & -1.6773 & $\mathrm{O}$ & 15.385 & $10 \%$ & 4 \\
\hline RES1 & Staf terampil dalam melayani konsumen & -1.0000 & $\mathrm{O}$ & 11.038 & $8 \%$ & 5 \\
\hline RES2 & Staf tanggap terhadap permintaan konsumen & -1.1364 & M & 5.088 & $3 \%$ & 13 \\
\hline RES3 & Pelayanan pesanan makanan dan minuman yang cepat & -1.2227 & $\mathrm{O}$ & 8.755 & $6 \%$ & 10 \\
\hline A2 & Fasilitas safety di pesawat yang terjamin mutunya & -1.1318 & M & 5.289 & $4 \%$ & 12 \\
\hline E3 & $\begin{array}{l}\text { Staf mampu memahami dan peduli terhadap kebutuhan } \\
\text { konsumen }\end{array}$ & -1.2500 & $\mathrm{O}$ & 10.432 & $7 \%$ & 6 \\
\hline \multirow[t]{2}{*}{$\mathrm{E} 4$} & $\begin{array}{l}\text { Staf dapat menyampaikan informasi dengan jelas dan } \\
\text { akurat }\end{array}$ & -1.2636 & M & 5.393 & $4 \%$ & 11 \\
\hline & & & & Average & $8 \%$ & \\
\hline
\end{tabular}


atribut tersebut cenderung tinggi, selisihnya dengan kenyataan cenderung besar, dan berdasarkan kano dianggap akan berkontribusi terhadap kepuasan.

\section{Integrasi Servqual, Model Kano, dan QFD}

Berdasarkan hasil perhitungan pada servqual dan model kano maka diperoleh tiga belas atribut yang termasuk ke dalam true customer needs. Atribut yang termasuk ke dalam true customer needs akan dijadikan customer requirements dalam QFD. Struktur HOQ pada penelitian ini merujuk pada struktur HOQ yang sudah disesuaikan sesuai dengan framework QFD integrasi Model Kano (Tan dan Pawitra, 2001). Dua hasil utama pada HOQ digambarkan pada Tabel 5 dan Tabel 6 .

Berdasarkan hasil perhitungan adjusted importance, diperoleh lima customer requirements yang akan diprioritaskan. Customer requirements ini diprioritaskan atas dasar pertimbangan bahwa nilai persentase adjusted importance kelima customer requirements ini melebihi rata-rata seluruh persentase customer requirements. Customer requirements yang diprioritaskan akan dirumuskan rekomendasi perbaikannya.

Technical requirements adalah aspek yang harus diperbaiki untuk dapat memenuhi customer requirements. Dari hasil perhitungan dengan melibatkan aspek hubungan antara customer requirements dan technical requirements, diperoleh 8 technical requirements yang diprioritaskan. Pertimbangan dalam pemilihan prioritas adalah berdasarkan perbandingan dengan rata-rata persentase kontribusi. Terdapat 8 technical requirements yang memiliki nilai persentase kontribusi di atas persentasi rata-rata seluruh technical requirements. Delapan technical requirements yang diprioritaskan adalah kebersihan ruangan, frekuensi perawatan fasilitas maskapai, perbaikan fasilitas maskapai, pengelolaan schedulling system, kemampuan manajemen maskapai, staf service excellence, perbaikan perilaku staf maskapai, dan tersedianya perangkat fasilitas maskapai yang modern. Technical requirements ini dimanfaatkan untuk membantu perumusan rekomendasi perbaikan. Perumusan rekomendasi perbaikan dilakukan dengan memperhatikan aspek kemampuan perusahaan, kondisi saat ini, dan benchmark. Hubungan antara customer requirements dan technical requirements terkait dengan perumusan rekomendasi perbaikan seperti ditunjukkan pada Tabel 7.

Rekomendasi yang disarankan untuk customer requirements "ketepatan waktu keberangkatan sesuai dengan jadwal yang telah ditetapkan" adalah waktu keberangkatan pesawat yang selalu sesuai dengan jadwal dan melakukan pemeriksaan rutin terhadap pesawat minimal dua kali sehari untuk mencegah adanya masalah teknis pada pesawat yang mengakibatkan delay. Jika memang terjadi keterlambatan, berikan penjelasan kepada penumpang penyebab delay apa dan estimasi waktu kedatangan pesawat dan perusahaan mengimplementasikan Peraturan Menteri Perhubungan KM 25/2008 tentang penyelenggaraan angkutan Udara di pasal 36 berkaitan dengan kompensasi kepada pelanggan bila

Tabel 6. Prioritas Technical Requirements

\begin{tabular}{|c|c|c|c|}
\hline Karakterisitik Teknis & $\begin{array}{c}\text { Tingkat } \\
\text { Kesulitan }\end{array}$ & $\begin{array}{c}\text { \% Importance of Technical } \\
\text { Requirements }\end{array}$ & Ranking \\
\hline Kebersihan ruangan & 1 & $6.42 \%$ & 6 \\
\hline Kondisi ruangan & 2 & $2.14 \%$ & 16 \\
\hline Kondisi bentuk fisik & 3 & $5.02 \%$ & 10 \\
\hline Frekuensi perawatan fasilitas maskapai & 1 & $10.03 \%$ & 2 \\
\hline Perbaikan fasilitas maskapai & 2 & $6.74 \%$ & 3 \\
\hline Pengelolaan scheduling system & 3 & $6.63 \%$ & 5 \\
\hline Kemampuan manajemen maskapai & 2 & $6.63 \%$ & 4 \\
\hline Efektivitas berbicara & 2 & $1.76 \%$ & 17 \\
\hline Staf service excellence & 2 & $13.27 \%$ & 1 \\
\hline Efektivitas berkomunikasi & 2 & $5.06 \%$ & 9 \\
\hline Perbaikan perilaku staf maskapai & 2 & $6.26 \%$ & 8 \\
\hline Jumlah staf maskapai & 2 & $3.60 \%$ & 14 \\
\hline Tersedianya perangkat fasilitas maskapai yang modern & 4 & $6.31 \%$ & 7 \\
\hline Kerjasama dengan distributor surat kabar/majalah & 2 & $3.40 \%$ & 15 \\
\hline Penggantian menu makanan & 2 & $1.67 \%$ & 18 \\
\hline Kemampuan cooking pramugari/pramugara & 2 & $5.02 \%$ & 13 \\
\hline Kerjasama dengan distributor makanan & 2 & $5.02 \%$ & 12 \\
\hline Bahan makanan & 1 & $5.02 \%$ & 11 \\
\hline & Average & $5.56 \%$ & \\
\hline
\end{tabular}


Tabel 7. Perumusan Rekomendasi Perbaikan

\begin{tabular}{|c|c|c|c|c|c|}
\hline $\begin{array}{c}\text { Kode } \\
\text { Atribut }\end{array}$ & $\begin{array}{c}\text { Customer } \\
\text { Requirements }\end{array}$ & $\begin{array}{c}\text { Kategori } \\
\text { Kano }\end{array}$ & $\begin{array}{c}\text { Karakteristik } \\
\text { Teknis }\end{array}$ & Existing & Rekomendasi \\
\hline RE1 & $\begin{array}{l}\text { Ketepatan } \\
\text { waktu } \\
\text { keberangkatan } \\
\text { sesuai dengan } \\
\text { jadwal } \\
\text { yang telah } \\
\text { ditetapkan }\end{array}$ & $\mathrm{O}$ & $\begin{array}{l}\text { Pengelolaan } \\
\text { scheduling } \\
\text { system } \\
\text { Frekuensi } \\
\text { perawatan } \\
\text { fasilitas } \\
\text { maskapai } \\
\text { Kemampuan } \\
\text { manajemen } \\
\text { maskapai }\end{array}$ & $\begin{array}{l}\text { Jadwal keberangkatan } \\
\text { masih sering terjadi delay } \\
\text { dan perusahaan belum } \\
\text { mengimplemntasikan } \\
\text { Peraturan Menteri } \\
\text { Peruhubungan KM } \\
25 / 2008 \text { tentang } \\
\text { kompensasi yang } \\
\text { diberikan kepada } \\
\text { pelanggan. }\end{array}$ & $\begin{array}{l}\text { Waktu keberangkatan pesawat yang selalu } \\
\text { sesuai dengan jadwal yang telah ditetapkan } \\
\text { sebelumnya dan melakukan pengecekan rutin } \\
\text { terhadap pesawat minimal dua kali sehari } \\
\text { untuk mencegah adanya masalah teknis } \\
\text { pada pesawat yang mengakibatkan delay. } \\
\text { Jika memang terjadi keterlambatan jelaskan } \\
\text { kepada penumpang penyebab delay apa dan } \\
\text { estimasi waktu kedatangan pesawat dan } \\
\text { perusahaan mengimplementasikan Peraturan } \\
\text { Menteri Perhubungan KM } 25 / 2008 \text { tentang } \\
\text { penyelenggaraan angkutan Udara di pasal } \\
36 \text { berkaitan dengan kompensasi kepada } \\
\text { pelanggan bila terjadi delay misal pemberian } \\
\text { meals ringan, makan, sampai dengan transit } \\
\text { hotel bila delay melebihi } 6 \text { jam. Dengan } \\
\text { ini diharapkan manajemen dapat bersikap } \\
\text { profesional dan juga tidak memberikan } \\
\text { perlakuan istimewa pada pelanggan tertentu. }\end{array}$ \\
\hline $\mathrm{T} 7$ & $\begin{array}{l}\text { Fasilitas } \\
\text { penyimpanan } \\
\text { bagasi yang } \\
\text { efisien }\end{array}$ & $\mathrm{O}$ & $\begin{array}{l}\text { Frekuensi } \\
\text { perawatan } \\
\text { fasilitas } \\
\text { maskapai } \\
\text { Perbaikan } \\
\text { fasilitas } \\
\text { maskapai }\end{array}$ & $\begin{array}{l}\text { Pengecekan yang } \\
\text { dilakukan oleh } \\
\text { perusahaan biasanya } \\
\text { hanya 1x dalam sehari } \\
\text { yaitu sebelum pesawat } \\
\text { digunakan. Dan untuk } \\
\text { fasilitas safety terdapat } \\
\text { beberapa bagasi yang } \\
\text { tidak berfungsi dengan } \\
\text { baik. }\end{array}$ & $\begin{array}{l}\text { Perusahaan melakukan pengecekan rutin } \\
\text { terhadap kondisi pesawat secara menyeluruh } \\
\text { hingga bagian kabin minimal 2x sehari dan } \\
\text { apabila terdapat bagasi yang tidak berfungsi } \\
\text { dengan baik segera diperbaiki berdasarkan } \\
\text { acuan Peraturan Menteri Perhubungan } \\
\text { Nomor KM } 24 \text { Tahun } 2009 \text { tentang Peraturan } \\
\text { Keselamatan Penerbangan Sipil Bagian } \\
139 \text { yang isinya mengatur ketentuan } \\
\text { tentang pelaksanaan penilaian risiko (risk } \\
\text { assessment) terhadap penyimpangan atau } \\
\text { tidak dipenuhinya fasilitas persyaratan standar } \\
\text { teknis pengoperasian. }\end{array}$ \\
\hline RES5 & $\begin{array}{l}\text { Staf terampil } \\
\text { dalam melayani } \\
\text { konsumen }\end{array}$ & $\mathrm{O}$ & $\begin{array}{l}\text { Staf service } \\
\text { excellence }\end{array}$ & $\begin{array}{l}\text { Perilaku staf dan } \\
\text { keterampilannya } \\
\text { dirasakan masih sangat } \\
\text { kurang oleh konsumen } \\
\text { saat ini terutama ketika } \\
\text { pelayanan ticketing } \\
\text { counter dan check in. }\end{array}$ & $\begin{array}{l}\text { Perusahaan dapat menerapkan program } \\
\text { airlines staff service excellence yang } \\
\text { dijabarkan secara lengkap pada Gambar V.2 } \\
\text { dalam mencapai pelayanan staf yang dapat } \\
\text { memuaskan pelanggan melebihi ekspektasi } \\
\text { sehingga pada ujungnya dapat memperbaiki } \\
\text { perilaku staf secara menyeluruh }\end{array}$ \\
\hline & & & $\begin{array}{l}\text { Perbaikan } \\
\text { perilaku staf } \\
\text { maskapai }\end{array}$ & & \\
\hline
\end{tabular}


Lanjutan Tabel 7.

\begin{tabular}{|c|c|c|c|c|c|}
\hline $\begin{array}{c}\text { Kode } \\
\text { Atribut }\end{array}$ & $\begin{array}{c}\text { Customer } \\
\text { Requirements }\end{array}$ & $\begin{array}{c}\text { Kategori } \\
\text { Kano }\end{array}$ & $\begin{array}{c}\text { Karakteristik } \\
\text { Teknis }\end{array}$ & Existing & Rekomendasi \\
\hline \multirow[t]{3}{*}{ RE5 } & $\begin{array}{l}\text { Makanan di } \\
\text { pesawat yang } \\
\text { enak dan } \\
\text { berkualitas }\end{array}$ & $\mathrm{O}$ & $\begin{array}{l}\text { Kemampuan } \\
\text { cooking } \\
\text { pramugari/ } \\
\text { pramugara }\end{array}$ & $\begin{array}{l}\text { Kondisi makanan ringan } \\
\text { yang diberikan di pesawat } \\
\text { sangat jauh dari yang } \\
\text { namanya makanan bergizi } \\
\text { karena pelanggan hanya } \\
\text { mendapatkan roti tawar } \\
\text { dan air mineral saja. Dan } \\
\text { makanan yang dapat } \\
\text { dipesan di pesawat sangat } \\
\text { terasa hambar. }\end{array}$ & $\begin{array}{l}\text { Dengan mempertimbangkan aspek finansial } \\
\text { sebelumnya perusahaan dapat memberikan } \\
\text { Training Customer Service jenis Cooking } \\
\text { Class kepada para pramugari/pramugara. } \\
\text { Hal ini dapat dilakukan dengan mengadakan } \\
\text { kerjasama dengan salah satu penyelenggara } \\
\text { kursus memasak profesional seperti Jakarta } \\
\text { Culinary Center atau penyelenggara kursus } \\
\text { memasak yang lain. Melalui hal ini nantinya } \\
\text { perusahaan dapat memberikan makanan yang } \\
\text { menggunakan bahan yang berkualitas dan } \\
\text { halal serta hendaknyamelakukan penggantian } \\
\text { menu makanan yang ada agar konsumen } \\
\text { tidak bosan dan untuk makanan ringan yang } \\
\text { menjadi satu paket dengan tiket, perusahaan } \\
\text { dapat bekerjasama dengan distributor makanan } \\
\text { setempat yang berkualitas seperti Bali Bakery. }\end{array}$ \\
\hline & & & $\begin{array}{l}\text { Penggantian } \\
\text { menu makanan }\end{array}$ & & $\begin{array}{l}\text { Kualitas makanan sangatlah penting } \\
\text { mengingat konsumen Batavia Air berdasarkan } \\
\text { profil demografis responden sebagian besar } \\
\text { merupakan wanita dan konsumen dengan usia } \\
\text { dari } 20-50 \text { tahun, yang sangat mementingkan } \\
\text { kualitas makanan yang bergizi. }\end{array}$ \\
\hline & & & $\begin{array}{l}\text { Kerjasama } \\
\text { dengan } \\
\text { distributor } \\
\text { makanan } \\
\text { Bahan } \\
\text { makanan }\end{array}$ & & \\
\hline T3 & $\begin{array}{l}\text { Fasilitas } \\
\text { hiburan di } \\
\text { pesawat yang } \\
\text { menarik }\end{array}$ & $\mathrm{A}$ & $\begin{array}{l}\text { Terdapatnya } \\
\text { perangkat } \\
\text { fasilitas } \\
\text { maskapai yang } \\
\text { modern }\end{array}$ & $\begin{array}{l}\text { Hingga saat ini maskapai } \\
\text { penerbangan Batavia } \\
\text { Air belum memiliki } \\
\text { perangkat hardware } \\
\text { hiburan yang berkualitas } \\
\text { dan berteknologi dalam } \\
\text { mengatasi kebosanan } \\
\text { pelanggan ketika berada } \\
\text { di pesawat. }\end{array}$ & $\begin{array}{l}\text { Dengan sebelumnya mempertimbangkan dari } \\
\text { segi finansial perusahaan mampu memberikan } \\
\text { fasilitas hiburan yang berteknologi dan up } \\
\text { to date seperti mini tv di backseat tiap kursi } \\
\text { pesawat yang dilengkapi dengan headseat } \\
\text { bagi tiap kursi sehingga dapat tercapainya } \\
\text { pelayanan hiburan yang bertaraf internasional. } \\
\text { Namun apabila dilihat dari profil demografis } \\
\text { responden, rata-rata pengguna jasanya adalah } \\
\text { konsumen yang berusia } 20-40 \text { tahun yang } \\
\text { cenderung membutuhkan hiburan yang } \\
\text { menarik di pesawat ketika merasa bosan. Maka } \\
\text { rekomendasi ini diharapkan dipertimbangkan } \\
\text { oleh perusahaan sebagai nilai saing. }\end{array}$ \\
\hline
\end{tabular}

terjadi delay berupa pemberian meals ringan, makan, sampai dengan transit hotel bila delay melebihi 6 jam. Dengan ini diharapkan manajemen dapat bersikap profesional dan juga tidak memberikan perlakuan istimewa pada pelanggan tertentu.

Rekomendasi yang disarankan untuk customer requirements "fasilitas penyimpanan bagasi yang efisien" adalah melakukan pemeriksaan rutin terhadap kondisi pesawat secara menyeluruh hingga bagian kabin minimal dua kali sehari dan apabila terdapat bagasi yang tidak berfungsi dengan baik segera diperbaiki berdasarkan acuan Peraturan Menteri Perhubungan Nomor KM 24 Tahun 2009 tentang Peraturan Keselamatan Penerbangan Sipil Bagian 139 yang isinya mengatur ketentuan tentang pelaksanaan penilaian risiko (risk assessment) terhadap penyimpangan atau tidak dipenuhinya fasilitas persyaratan standar teknis pengoperasian. Sedangkan rekomendasi yang disarankan untuk customer requirements "staf terampil dalam melayani konsumen" adalah perusahaan dapat menerapkan program airlines staff service excellence dalam mencapai pelayanan staf yang dapat memuaskan pelanggan melebihi ekspektasi sehingga pada akhirnya dapat memperbaiki perilaku staf secara menyeluruh.

Rekomendasi yang disarankan untuk customer requirements "makanan di pesawat yang enak dan berkualitas" adalah dengan memberikan training customer service jenis cooking class kepada para 
pramugari/pramugara (setelah mempertimbangkan dari segi finansial perusahaan). Hal ini dapat dilakukan dengan mengadakan kerjasama dengan salah satu penyelenggara kursus memasak professional seperti Jakarta Culinary Center atau penyelenggara kursus memasak yang lain. Melalui hal ini nantinya perusahaan dapat memberikan makanan yang menggunakan bahan yang berkualitas dan halal serta hendaknya melakukan penggantian menu makanan yang ada agar konsumen tidak bosan dan untuk makanan ringan yang menjadi satu paket dengan tiket, perusahaan dapat bekerjasama dengan distributor makanan setempat yang berkualitas seperti Bali Bakery. Kualitas makanan sangat penting mengingat konsumen maskapai penerbangan $\mathrm{X}$ berdasarkan profil demografis responden sebagian besar merupakan wanita dan konsumen dengan usia dari 20-50 tahun, yang sangat mementingkan kualitas makanan yang bergizi.

Rekomendasi yang disarankan untuk customer requirements "fasilitas hiburan di pesawat yang menarik" adalah memberikan fasilitas hiburan yang berteknologi dan up to date seperti mini tv di backseat tiap kursi pesawat yang dilengkapi dengan headseat bagi tiap kursi sehingga dapat tercapainya pelayanan hiburan yang bertaraf internasional (setelah mempertimbangkan dari segi finansial perusahaan). Namun apabila dilihat dari profil demografis responden, rata-rata pengguna jasanya adalah konsumen yang berusia 20-40 tahun yang cenderung membutuhkan hiburan yang menarik di pesawat ketika merasa bosan, maka rekomendasi ini diharapkan dipertimbangkan oleh perusahaan sebagai nilai saing.

\section{SIMPULAN}

Berdasarkan hasil pengolahan dan analisis data serta rekomendasi yang telah dilakukan, terdapat 30 atribut layanan maskapai penerbangan $\mathrm{X}$ yang dapat diidentifikasi menggunakan dimensi Servqual. Selanjutnya berdasarkan pengolahan data Servqual, diperoleh 14 atribut yang tidak memenuhi ekspektasi pelanggan atau masih berada di bawah harapan konsumen. Identifikasi atribut layanan maskapai penerbangan X menggunakan Model Kano diperoleh 19 atribut layanan yang termasuk kategori one dimensional, 8 atribut layanan yang termasuk kategori must be, 1 atribut layanan yang termasuk kategori attractive dan 2 atribut layanan yang termasuk dalam kategori indifferent. Langkahlangkah perbaikan yang dapat dilakukan oleh maskapai penerbangan $\mathrm{X}$ dalam meningkatkan kualitas layanannya adalah pengecekan rutin untuk mencegah keterlambatan, pemberian kompensasi pada saat terjadi keterlambatan, penerapan program airlines staff service excellence, penerapan program cooking class, dan pemberian fasilitas hiburan yang berteknologi dan up to date pada pesawat.

\section{DAFTAR PUSTAKA}

Cohen, L., dan Joseph. P. F., 2009. Quality Function Deployment and Six Sigma: A QFD Handbook. $2^{\text {nd }}$ Edition. Prentice Hall.

Parasuraman, A., Zeithaml, V.A., dan Berry L.L., 1996. The Behavioral Consequences of Service Quality. Journal of Marketing, 60 (2), 31-46.

Politis, J. D., 2005. QFD, Organizational Creativity, and Productivity. International Journal of Quality and Reliability Management, 22 (1), 59-71.

Rao, A., 1996. Total Quality Management: A Cross Functional Perspective. John Willey and Sons. 401.

Tan, K.C. dan Pawitra, T.A., 2001. Integrating SERVQUAL and Kano's Model into QFD for Service Excellence Development. Journal Managing Service Quality, 11 (6), 418-430.

Ulrich, K.T. dan Epingger, S.D., 2008. Product Design and Development. Mc Graw Hill International Edition. 